\title{
LANDFILL AIR POLLUTION BY ULTRAFINE AND MICROPARTICLES IN CASE OF DRY AND WINDLESS WEATHER CONDITIONS
}

\section{Emília Hroncová *, Juraj Ladomerský and Denisa Ladomerská}

European Science and Research Institute, Hlinku 29, 96001 Zvolen, Slovakia
Article Info:
Received:
2 August 2019
Revised:
23 January 2020
Accepted:
4 February 2020
Available online:
5 March 2020
Keywords:
Landfill
Air pollution
Ultrafine particles
Microparticles
Windless weather

\begin{abstract}
In the present article we give the results for ultra-fine particles and microparticles at a landfill of municipal waste, taking into consideration various factors. The landfill is a large-scale source of dust. There is little knowledge in terms of fractional composition of dust particles. We have performed concentration measurements of the number of ultrafine (10 to $100 \mathrm{~nm})$ and microparticles $(0.1$ to $10 \mu \mathrm{m})$ in the field conditions of the municipal waste landfill using the TSI Technique (Optical particle sizer 3330 and Nanoscan SMPS nanoparticle sizer 3910). The particle number concentration in the atmosphere in case of dry and windless weather conditions at the landfill was in the range of about 2,500 to 5,500 of ultrafine particles per $\mathrm{cm}^{3}$. The mass concentrations of the microparticles was in the range of 29 to $163 \mu \mathrm{g} \cdot \mathrm{m}^{-3}$ (assuming $\rho=1 \mathrm{~g}_{\mathrm{ccm}}^{-3}$ ). There was an evident trend of increase of concentration of the ultrafine particles and microparticles in the lower location of the landfill occuring in the case of dry and windless weather conditions. The surprising finding was that passing haulage vehicles and in particular the operation of the compactor increase the mass concentration of microparticles, but they do not increase the concentration of the number of microparticles or even of ultrafine particles.
\end{abstract}

\section{INTRODUCTION}

The field of air pollution control has seen an intensive process of awareness-raising regarding the seriousness of air pollution caused by particles as well as measures to reduce it. It is considered that air pollution by particles shortens life expectancy. According to the methodology of the World Health Organization WHO, 400 people die in Slovakia every year due to urban high mean concentration of $\mathrm{PM}_{10}$ particles $31 \mu \mathrm{g} \cdot \mathrm{m}^{-3}$ (Country profiles of Environmental Burden of Disease - Slovakia, 2009). In the Czech Republic it is 1,700 deaths per year (Country profiles of Environmental Burden of Disease - Czech Republic, 2009).

The European Commission continuously reports violations of air quality standards, and points out that air pollution by $\mathrm{PM}_{25}$ particles claimed 436,000 lives in $28 \mathrm{EU}$ countries in 2013 (Crisp, 2017). These findings are of key importance for the waste management domain, as almost all its activities produce particles of various sizes, which subsequently become airborne. Many waste management activities are performed outdoors or in large factories with their doors open, and become the source of diffuse or fugitive emissions.

It is generally known that mineral particles with an aerodynamic diameter of $>30 \mu \mathrm{m}$ are subject to deposition ranging up to 100 metres from the source, particles with a diameter 30-10 $\mu \mathrm{m}$ from 250-500 metres, but particles smaller than $<10 \mu \mathrm{m}$ can be deposited as far as 1 kilometre. Particles $<2.5 \mu \mathrm{m}$ practically do not settle or deposit. However, it is interesting that the dispersion rate of ultrafine particles $<100 \mathrm{~nm}$ is much slower than the dispersion rate of gases. Particles of organic substances have lower density and thus deposit at a lower rate.

The most common mechanical processes of waste management such as grinding, shredding and separation of fractions are sources of aerosols and bioaerosols. Bioaerosols are solid airborne particles carrying microorganisms or their fragments. A serious bioaerosol contamination risk may occur as a result of long-term storage of waste containing even a small amount of organic material.

Landfilling is a typical activity of waste management and it is the main source of diffuse emissions. It is considered that all works on the landfill especially truck traffic and operation of a compactor, unloading of waste and compacting it (dumping and spreading of waste by compactor), manipulation of the daily cover, wind erosion, burning of landfill gas, is the source of emissions of microparticles and maybe of ultrafine particles. The size of the active face of the landfill is also very important. Workers at a landfill site may be exposed to high concentrations of aerosols, which contain various mineral and organic fibres, bioaer- 
osols, crystalline $\mathrm{SiO}_{2}$, metals etc. The amount of windblown particles from a landfill depends on the wind speed, weather (drought spells, rain, snow cover), the surface conditions of the roads connecting individual deposits of waste at the landfill as well as the landfill itself and the size of the particles on its surface.

Lanfills of waste are particularly interesting as a source of energy, as well as from the point of view of global climate change and emissions of various gaseous pollutants (EPA, 2008; US EPA, 2015; Chalvatzaki, Lazaridis 2010). Landfills of waste are studied in a lesser extent as a source of microparticles and ultrafine particles and their dispersion into the environment is studied even less. The lowest emissions of the particles on the surface of a landfill can be observed on a wet surface or during rain. Therefore, wetting the surface can be used as a secondary measure to alleviate pollution during dry and windy weather conditions. Daily cover is also of high importance at a landfill. There is even a patented procedure to reduce dustiness at the site by spraying the surface by concentrated solution of boric acid or a diluted solution of polyethylene glycol and boric acid (Keith K. McDamel, 1987).

It is quite difficult to carry out medical studies concerning people working at landfills or the population living in their vicinity, but also other related waste management activities due to numerous exposition channels of harmful pollutants and toxicological diversity (WHO - Europe, 2007). Prior studies addressing waste management discuss almost exclusively $\mathrm{PM}_{10}$ and $\mathrm{PM}_{2.5}$ particles although ultrafine particles can be much more detrimental (Macklin et al., 2011).

Nowadays, waste management within the EU often uses e.g. composting or mechanical-biological waste treatment, which are generally considered to be nature-friendly activities (COM, 2008). Such activities are finding their way to landfills too. However, establishing and ventilation of compost heaps as well as finalising of the composting process and subsequent sifting of compost turns the composter into a source of bioaerosols. The workers may be exposed to high concentration of aerosols and bioaerosols when performing their activities at a compost site. The production of microbial aerosols by urban sewage treatment plants may have wide hygienic implications which call for careful evaluation: exposure to such aerosols may in fact represent a health hazard for plant workers and nearby residents alike (Carducci et al., 2000).

The scientific knowledge about the impact of ultrafine particles (UFPs) on human health (cardiovascular system, respiratory diseases) is not so extensive as it is in the case of $\mathrm{PM}_{10}$ and $\mathrm{PM}_{2.5}$ particles. Furthermore, there is no database of the sources of these particles in the working environment. Even less information is available on the impact of higher concentrations of airborne UFPs and no limits have been defined yet. Therefore, the measurement of the concentration of particles is an important tool with respect to introducing measures to curb dustiness and evaluate their effectiveness.

This paper aims to analyse the quality of air from the perspective of its pollution by ultrafine particles and microparticles at a selected municipal waste landfill. The measure- ment was performed in stable, dry and calm weather, when air quality is not influenced by wind erosion and dispersed wind-blown particles. Even under the mentioned conditions it is important to compare the concentrations of the number and size distribution of UFPs or weight concentrations of microparticles with the background concentration in the vicinity of the landfill. It is not known yet whether the landfill can permanently increase the level of ultrafine particles and microparticles in the nearby villages ( 2 to $4 \mathrm{~km}$ ), and whether it poses any risks for the population. The results obtained, together with next measurements of downwind concentrations of the aforementioned particles at a wind speed over $6 \mathrm{~m} . \mathrm{s}^{-1}$ (planed next measurments), will confirm suitability of the landfill technology, or indicate a need to introduce further measures to achieve their reduction.

The relative significance of air pollution by particles is different for each waste management facility. It depends on its type, size, duration of its operation as well as the nature of its waste. Furthermore, there are a number of external factors which affect its emitting and dispersion such as meteorological conditions especially rainfall and wind force. Topography can also play a role as to whether waste management operations are performed inside buildings or outdoors. Each landfill is unique with respect to age, quantity and type of waste contained, daily cover, adherence to working processes, local meteorology, hydrogeology, and engineering control of leachate and landfill gas and monitoring.

\section{MATERIALS AND METODS}

\subsection{Site selection and measurement conditions}

The measurements of air pollution were performed at a typical municipal waste landfill site in Central Slovakia. The landfill site is used to dispose of non-hazardous waste within the meaning of the Decree of the Ministry of the Environment No. $371 / 2015$ Coll. The landfill is able to manage more than 10 tonnes per day with a total capacity of more than 25,000 tonnes, the volumetric capacity of the landfill is $264,401 \mathrm{~m}^{3}$ and its surface area is $12,300 \mathrm{~m}^{2}$. A compost site for biological waste (open windrow heaps) was established on part of the site of a former landfill.

The closest municipality is located $2 \mathrm{~km}$, to the northwest (measured from the centre of the landfill), the other is situated $2 \mathrm{~km}$ northwest, the third is $3 \mathrm{~km}$ away to the northeast, and the fourth village is $4 \mathrm{~km}$ to the southwest of the landfill (Figure 1).

The measurement was conducted at the landfill on a single day. A period of dry and hot windless weather (temperature $22-30^{\circ} \mathrm{C}$ wind speed below $1 \mathrm{~m} . \mathrm{s}^{-1}$ ) was selected to obtain accurate information on the lowest pollution rate in the vicinity of the landfill. Ultrafine particles and microparticles are not dispersed in this weather, if we do not consider rain conditions. Measurements were carried out in the period of stable weather, minimally five windless days without rain in a row.

Sampling sites were situated at critical locations where the movement of the workers and machinery is concentrated, including trucks, dumping and spreading of waste by excavator and compactor over a currently used landfill cell as well as compacting. Figure 2 shows the plan of the ac- 


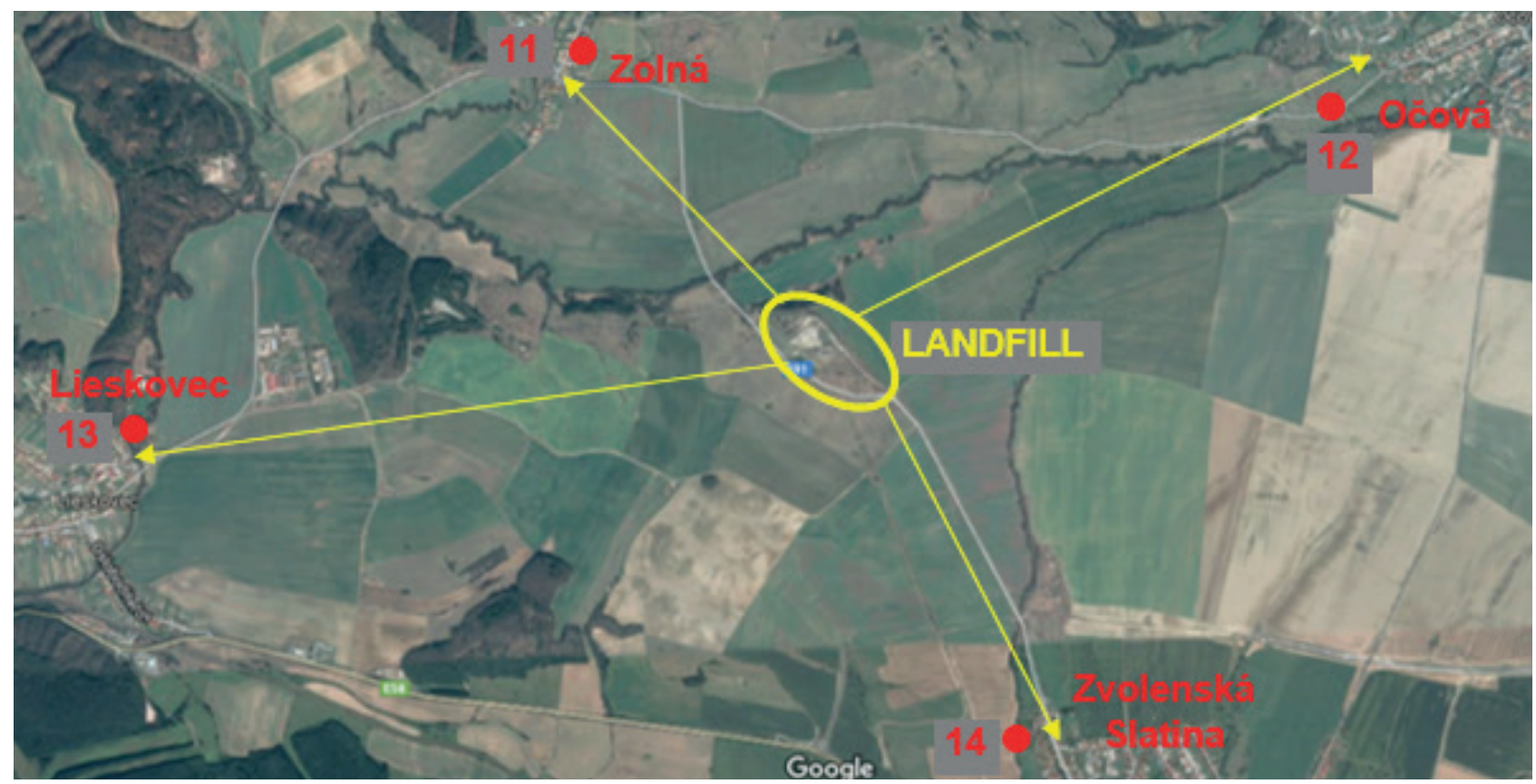

FIGURE 1: Map of broader relations with the sampling sites outside the landfill site (Sampling sites: No. 11 Zolná, No. 12 Očová, No. 13 Lieskovec, No. 14 Zvolenská Slatina).

tive zone at the landfill site with the sampling sites marked. Not all the airborne or deposited particulate matter around the landfill site will be caused by the facility itself. Therefore, additional sampling sites were designated outside the landfill in the direction towards the individual municipalities. The map of sampling sites outside the landfill site towards surrounding villages is shown in Figure 2.

\section{Sampling sites:}

- $\quad \mathrm{N}^{\circ} 1$ - Truck scale for weighing loaded and unloaded vehicles after dumping the waste (no passing through);

- $\quad N^{\circ} 2$ - Truck scale (6 vehicles can pass through);

- $\mathrm{N}^{\circ} 3$ - Under the landfill at a direct distance of approximatelly $40 \mathrm{~m}$ from the compactor (when in operation) and 13 metres below the top of the site;

- $\mathrm{N}^{\circ} 4$ - Under the landfill, direct distance of $30 \mathrm{~m}$ from the compactor (when in operation) and 13 metres below the top of the site;

- $\quad \mathrm{N}^{\circ} 5$ - In immediate proximity to the operating compactor;

- $\quad N^{\circ} 6-2$ m below the top of the landfill site (with compactor in operation);

- $\quad \mathrm{N}^{\circ} 7-2$ m below the top of the landfill site (with compactor in operation) and 2 vehicles can pass through;

- $\quad \mathrm{N}^{\circ} 8$ - At the top of the landfill site (compactor in operation);

- $\quad N^{\circ} 9$ - At the top of the landfill site (compactor out of operation) $15 \mathrm{~m}$ away from the compactor;

- $\quad \mathrm{N}^{\circ} 10$ - The compost site (under the landfill, direct distance $120 \mathrm{~m}$ from the compactor (when in operation) and 15 metres below the top of the site.

Two parallel 10-minute long measurements were taken with 1-minute sampling interval at each sampling site. The interval between parallel measurements min. $2 \mathrm{~h}$. Mean values were calculated from these minute values.

\subsection{Methods for determining the concentration of ultrafine particles and microparticles}

Particles ranging between $10 \mathrm{~nm}$ to $10 \mu \mathrm{m}$ were analysed by means of two analysers manufactured by TSI Incorporated, Minnesota USA. They were NanoScan SMPS Model 3910 (portable separator and particle counter with size magnitude from 10 to $350 \mathrm{~nm}$ ) and Optical Particle Sizer Model 3330 (portable separator and particle counter with size magnitude 0.3-10 $\mu \mathrm{m}$ ). The air samples were taken $1.5 \mathrm{~m}$ above the ground.

\subsubsection{NanoScan SMPS Model 3910, TSI}

The principle is to determine the particle number of

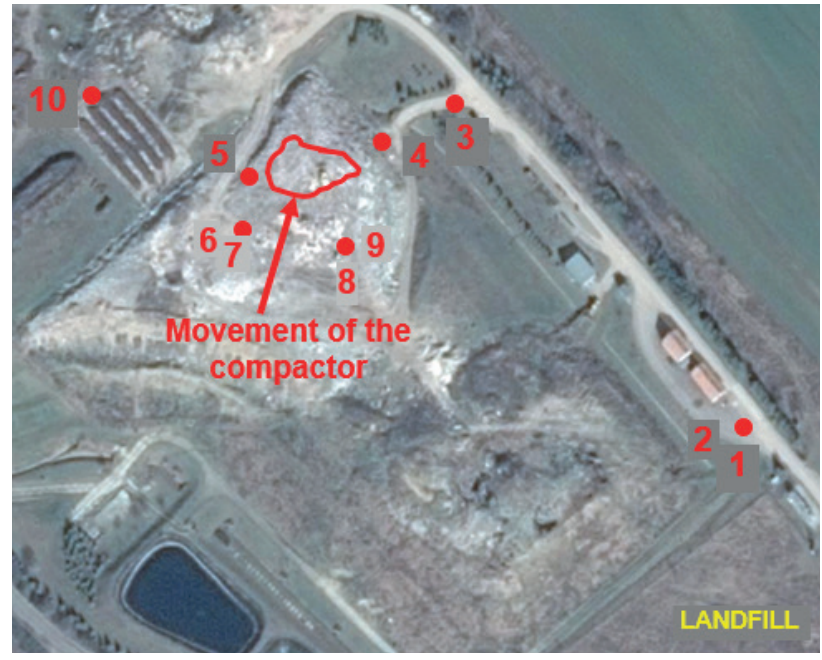

FIGURE 2: Layout of the landfill site with the sampling sites marked. 
specific sizes contained in a given air sample. The particles are electrically charged and afterwards separated in an electrical field based on their size and electric charge. Eventually, a computer evaluates the particle count for each fraction. The device is equipped with a pre-conditioner, which removes larger particles (particles larger than $420 \mathrm{~nm}$ ). Finer particles are charged by corona discharge, then they enter the size selector where they are separated into thirteen channels based on their size and finally they are counted in the isopropanol-based particle counter. The measurable concentration of particles in the aerosol is up to $10^{6}$ particles. $\mathrm{cm}^{-3}$, accuracy 1 particle. $\mathrm{cm}^{-3}$. Sampling time is 1 second and the airflow through the device is minimum 1 I. $\mathrm{min}^{-1}$.

\subsubsection{Optical Particle Sizer Model 3330, TSI}

A sample of examined air is sucked directly into an optical chamber where it passes through a light beam. Size resolution is based on the principle of light scattering. The sample then passes through a chamber equipped with a filter for measuring PM weight by gravimetric method or for the purposes of other chemical or microscopic analyses. The size range of identified particles is $0.3-10 \mu \mathrm{m}$. in at least 13 size channels. The minimum measurement range: mass concentration $0.001-275,000 \mu \mathrm{g} \cdot \mathrm{m}^{-3}$, particle concentration range 1-3,000 particles. $\mathrm{cm}^{-3}, 1$ particle. $\mathrm{cm}^{-3}$, size resolution $<5 \%$ at $0.5 \mu \mathrm{m}$. Sampling time is $1 \mathrm{~s}$ and gas flow rate is min. 1 I. min $^{-1}$.

Concentrations of ultrafine particles raging from 10 to
$100 \mathrm{~nm}$ and from 100 to $300 \mathrm{~nm}$ were obtained from NanoScan SMPS Model 3910, and the values for the range 100-300 nm, assigned to microparticles, were provided by Optical Particle Sizer Model 3330.

\section{RESULTS AND DISCUSSION}

Operations at a landfill site take place over a large area (hectares) throughout the year, but a compactor covers a rather smaller area (hundreds of $\mathrm{m}^{2}$ ) per day. The measurement results of ultrafine particle concentration are shown in Figure. 3.

There is still not sufficient knowledge of ultrafine particles especially because for decades research has been based on measurements of mass concentration. Therefore, no limits for airborne ultrafine particles have been defined. Their mass is much smaller than $\mathrm{PM}_{10}$ and $\mathrm{PM}_{2.5}$, so the particle number concentration has the highest evidential value. Air with ultrafine particle concentration less than approximately 4,000 per $\mathrm{cm}^{3}$ is considered clean (Morawska et al. 2009, Hama et al., 2015). Typical urban background UFP concentration is 10,760 particles. $\mathrm{cm}^{-3}$ (Morawska et al. 2008).

As there are no limits for ultrafine particles in place, it is important to know the concentration of the particles in question at the exposed sites. Furthermore, it is important whether the particles are dispersed in the vicinity of the operation and whether there is a link between activities performed at the site and the potential concentration maximum. The data in Figure 3 demonstrate that even in calm-

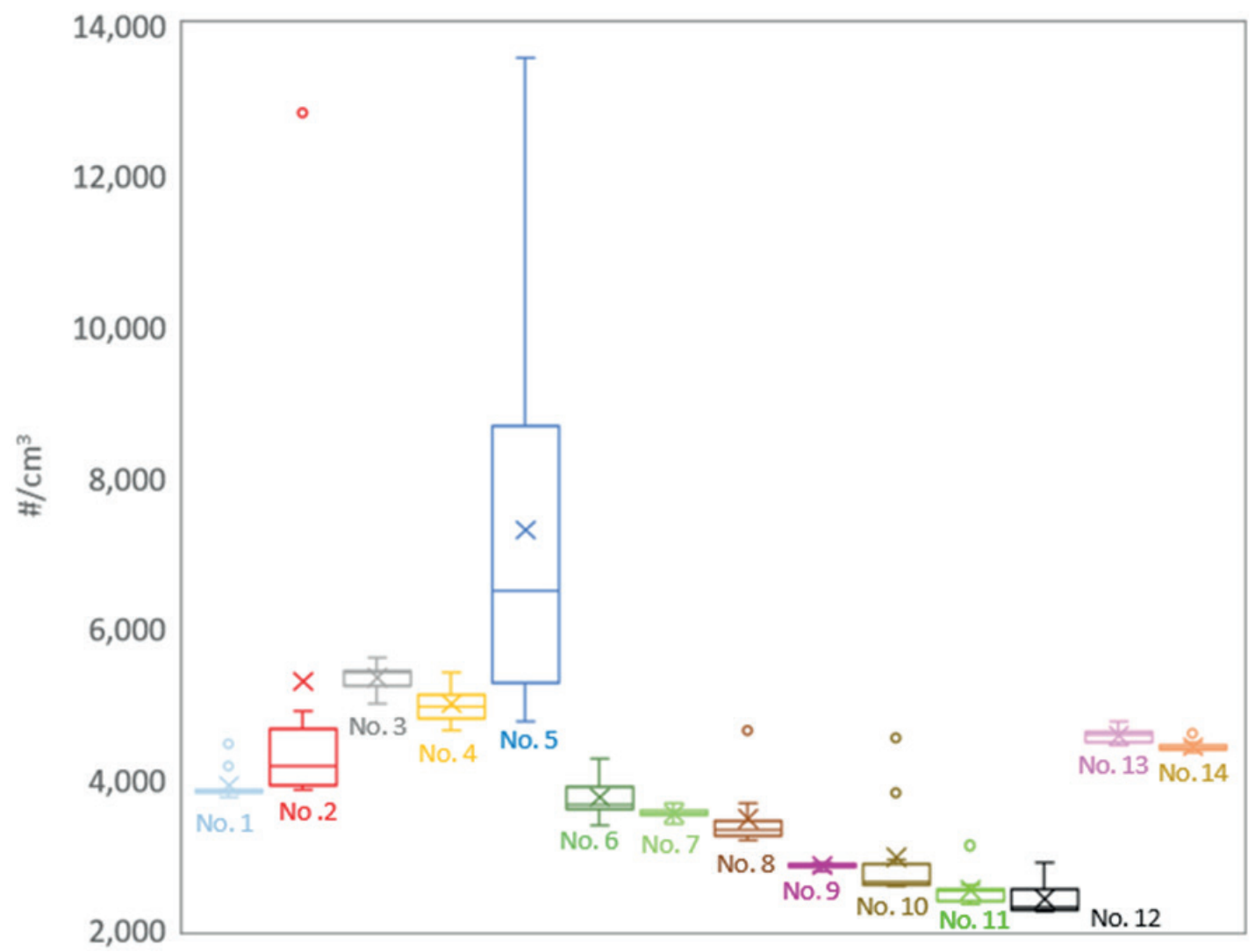

FIGURE 3: Boxplots of ultrafine particle number concentrations at the waste facility and its surroundings; x-axis No of sampling site and $\mathrm{y}$-axis is particle number concentration. 
weather there are low particle number concentrations with the exception of the landfill site sampling sites No. 2-5.

Figure 3 shows two sampling sites (No 2 and 5), which differ from the others regarding ultrafine particle number concentrations. Sampling site No. 2 was located right next to the scale for weighing full and empty trucks. 6 trucks passed through over a period of 20 minutes, which was manifested in a short surge in the particle number concentration. The concentrations differed considerably at the same location sampling site No. 1 when there were no vehicles in operation. The operation of a compactor exhibited a similar effect. The highest concentrations ranging with max 13,558 , were recorded in its immediate proximity (No. 5), but at the distance of $15 \mathrm{~m}$ from the compactor (No. 6, 7 and 8) the concentrations were much lower from 3,190 to 4,640. A brief interruption of its operation caused an even further drop in the concentrations (No. 9). In general, these data suggest that even in calm weather, ultrafine particle number concentrations decreased considerably with increasing distance from the source. This trend is confirmed by the measurement results obtained at the sampling site No. 10 and outside the facility at sites 11 and 12 . The exception is sampling site No.13 and partly No. 14. In the first case, the air pollution can be generated by large sources from a nearby industrial area ca $3.6 \mathrm{~km}$ away (energy production from biomass, production of chipboards, pyrolysis of waste, plastic etc.). The slightly higher concentration at the sampling site No. 14 in comparison with No. 11 and 12 may be partly due to the same industrial area or heavy truck traffic through the village of Zvolenská Slatina.

Another interesting fact is that the lowest-lying sections of the waste facility (sampling sites No. 3 and 4) exhibited high ultrafine particle number concentrations and they drop at the highest points of the landfill. It may mean that dispersion of the particles was less intensive in the lower layers, which may be related to long-lasting insufficient air circulation in these leeward parts of the landfill.

The surprising finding was that passing haulage vehicles and in particular the operation of the compactor increase the mass concentration of microparticles, but they do not increase the concentration of the number of microparticles in 0.3-10 $\mu \mathrm{m}$ (Figure 4) or even of ultrafine particles. It is mechanical generation of microparticles. Compactor pulverises the surface of landfill and ejects coarse particles to the air much more in comparison with the period when only trucks travel to offload garbage in the landfill cell. That confirms the results of the authors Chalvatzaki et al. (2015), who found out at the background area the percentage contributions of fine $\left(\mathrm{PM}_{2.1}\right)$ and coarse particles $\left(\mathrm{PM}_{10-2.1}\right)$ to $\mathrm{PM}_{10} 31$ and $69 \%$, respectively, while at the outdoor weighing facility on the landfill, they were 6 and $94 \%$, respectively.

Particle size distribution represents data important for examining how various sources of pollution influence particle number concentration at a specific location. Figure 5 shows the particle size distribution. These relations demonstrate that movement of vehicles as well as the operation of a compactor in the vicinity of the sampling site is

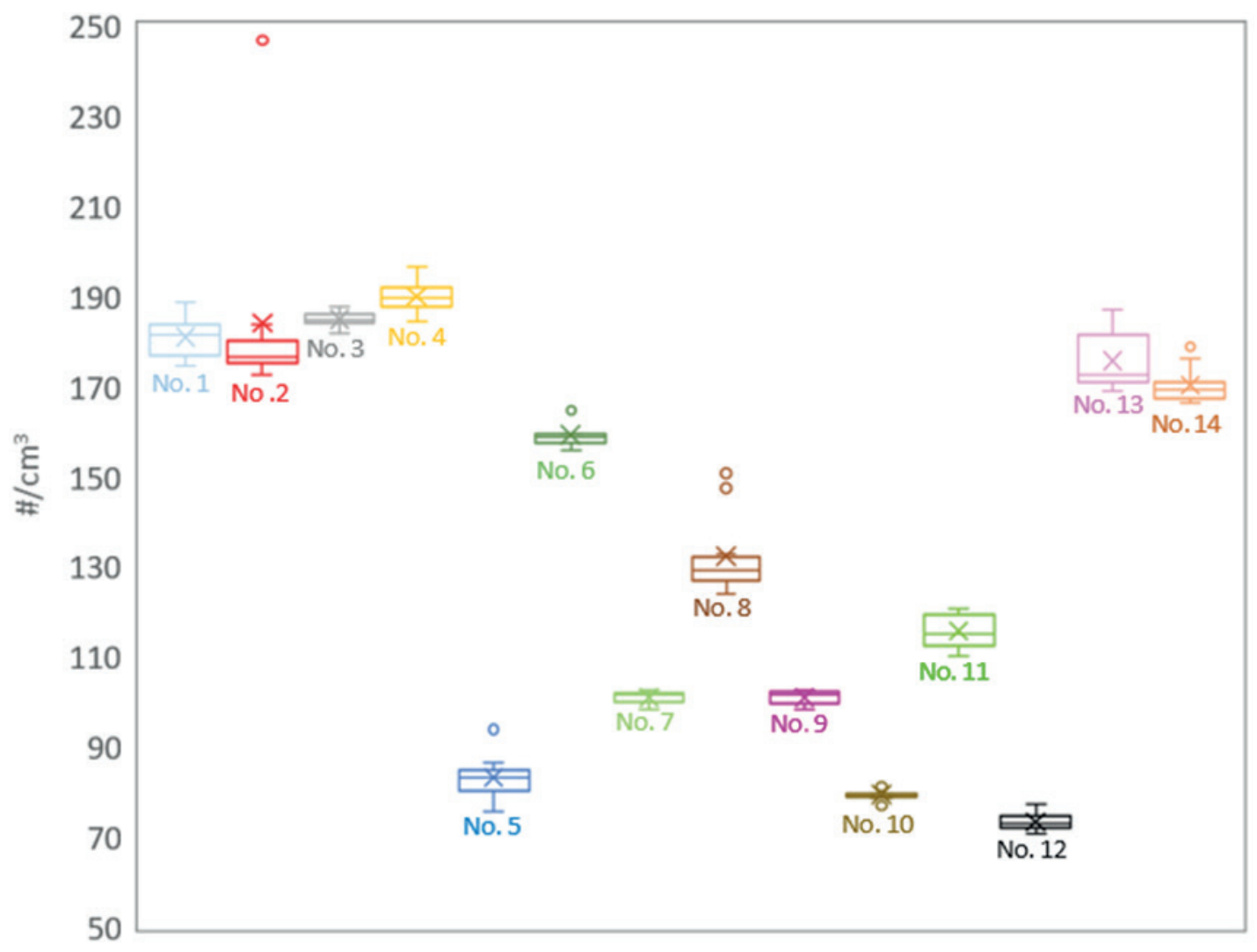

FIGURE 4: Boxplots of microparticle $(0.3-10 \mu \mathrm{m})$ number concentrations at the waste facility and its surroundings; $x$-axis No of sampling site and $y$-axis is particle number concentration. 
manifested in a bimodal distribution; in other cases there is a unimodal distribution at the landfill site. Particle size distribution at the sampling site No. 3 and 4 implies that there is poor air circulation in the lowest-lying leeward sections of the waste facility. This prevented faster diffusion of the finest fractions of ultrafine particles. This is also reflected in the fact that the correlation is bimodal.

An additional piece of data is the surface area, which may influence the level of risk to human health. The surface area concentration $\left[\mathrm{\mu m}^{2} . \mathrm{cm}^{-3}\right]$ is important in toxicology studies. Further information on the impacts of waste management activities on air pollution can be obtained from the proportion of ultrafine particles in the total particle number ranging from $10 \mathrm{~nm}-10 \mu \mathrm{m}$. Finally, from a relative perspective, the microparticle mass concentration can provide a full picture of the pollution. The aforementioned data are in Table 1.

The movement of vehicles was found to be the most significant factor with respect to the surface area concentration with the values of $100 \mu \mathrm{m}^{2} . \mathrm{cm}^{-3}$ at sampling site No.
2 , while the lowest measured value did not exceed 30 in case of the sampling sites 11 and 12. It should be taken into account that the value was only $39 \mu \mathrm{m}^{2} . \mathrm{cm}^{-3}$. Conversely, the proximity of the compactor at sampling site No. 5 , the proportion of ultrafine particles amounted to $83.6 \%$. The most evident impact of the compactor was observed when measuring the mass concentration of microparticles at $187 \mu \mathrm{g} \cdot \mathrm{m}^{-3}$.

The most representative attribute of microparticles is their mass concentration. The measurement devices do not determine actual values of the mass concentration, but yield data provided the particle density is $1 \mathrm{~g} . \mathrm{cm}^{-3}$. This value was used due to a lack of knowledge concerning more precise value of density of microparticles. The analysed relationships are not changed by using this value. Based on Table 1, it can be assumed that in some cases the microparticle mass concentrations will exceed the limits for outdoor areas of $50 \mu \mathrm{g} \cdot \mathrm{m}^{-3}$ (for $\mathrm{PM}_{10}$ ). Similarly, in other cases it was observed that $\mathrm{PM}_{10}$ concentrations were above this limit with values up to $275 \mu \mathrm{g} \cdot \mathrm{m}^{-3}$ (Chalvatzaki et

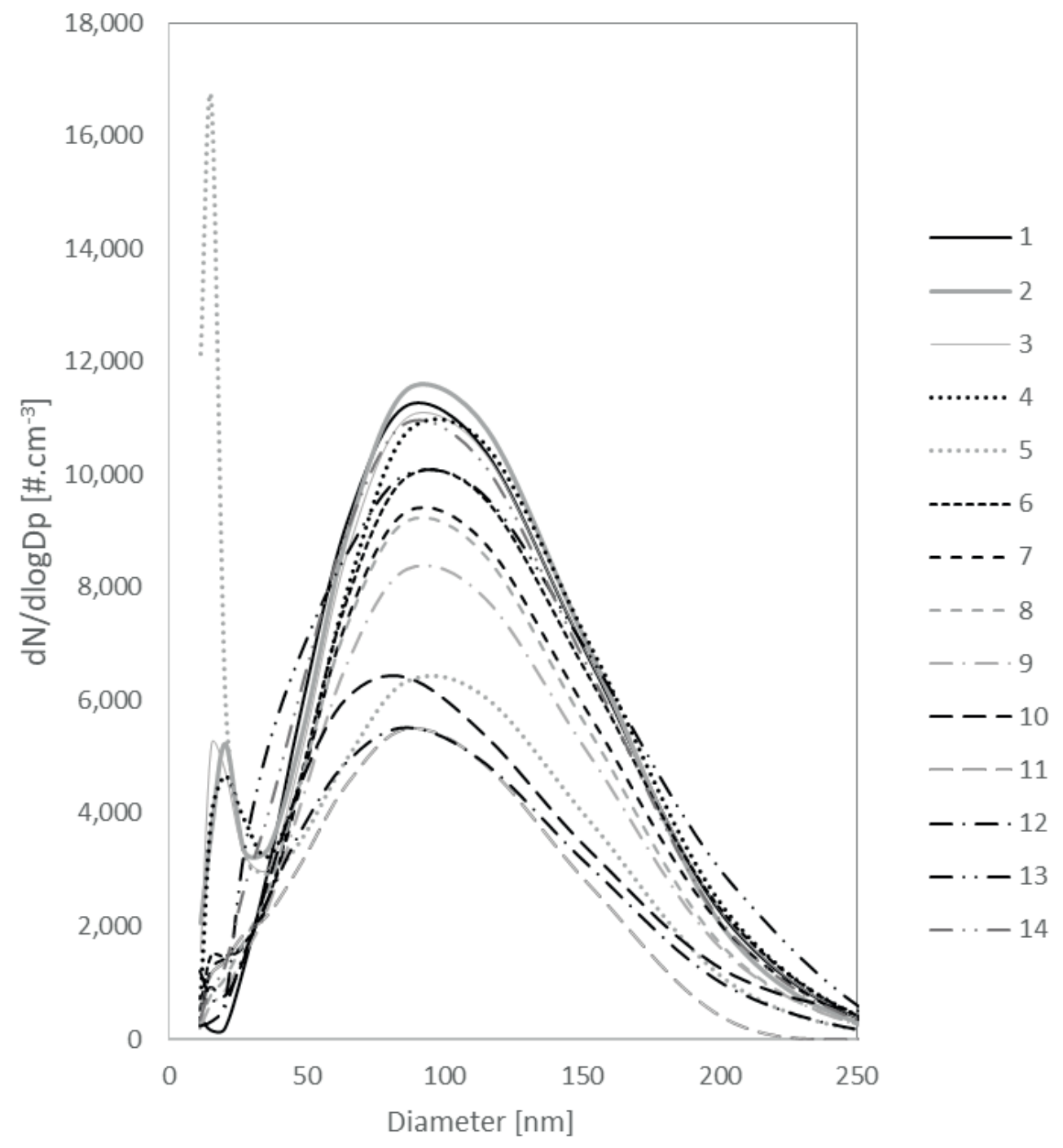

FIGURE 5: Particle size distribution for forteen sampling sites; $x$-axis - particle diameter $\mathrm{Dp}, \mathrm{y}$-axis - particle number concentration dN/ dlogDp. 
TABLE 1: Discharge conditions set by Severn Trent Water Limited on 14th August 2014, for wastewaters being discharged into the Upper Cole Valley Sewer.

\begin{tabular}{|c|c|c|c|c|}
\hline \multicolumn{2}{|c|}{ Sampling site\% } & \multirow{2}{*}{$\begin{array}{c}\begin{array}{c}\Delta U F P s \\
\mu^{2} / \mathbf{c m}^{3}\end{array} \\
60.6\end{array}$} & \multirow{2}{*}{$\begin{array}{c}\begin{array}{c}\mathbf{N}^{\star *} \\
\mu \mathbf{g} / \mathbf{m}^{3}\end{array} \\
55.7\end{array}$} & \multirow{2}{*}{$\begin{array}{c}M^{*} \\
46.4\end{array}$} \\
\hline No. 1 & $\begin{array}{l}\text { Truck scale for weighing loaded and unloaded vehicles after dumping the waste (no pas- } \\
\text { sing through) }\end{array}$ & & & \\
\hline No. 2 & Truck scale (6 vehicles can pass through) & 66.5 & 57.7 & 44.3 \\
\hline No. 3 & $\begin{array}{l}\text { Under the landfill at a direct distance of approximatelly } 40 \mathrm{~m} \text { from the compactor (when in } \\
\text { operation) and } 13 \text { metres below the top of the site }\end{array}$ & 67.7 & 55.6 & 46.1 \\
\hline No. 4 & $\begin{array}{l}\text { Under the landfill, direct distance of } 30 \mathrm{~m} \text { from the compactor (when in operation) and } 13 \\
\text { metres below the top of the site }\end{array}$ & 65.6 & 53.4 & 50.2 \\
\hline No. 5 & In immediate proximity to the operating compactor & 83.6 & 39.1 & 187.3 \\
\hline No. 6 & $\begin{array}{l}2 m \text { below the top of the landfill site } \\
\text { (with compactor in operation) }\end{array}$ & 61.2 & 48.8 & 36.4 \\
\hline No. 7 & $\begin{array}{l}2 \mathrm{~m} \text { below the top of the landfill site (with compactor in operation) and } 2 \text { vehicles can pass } \\
\text { through }\end{array}$ & 62.1 & 46.2 & 106.3 \\
\hline No. 8 & At the top of the landfill site (compactor in operation) $15 \mathrm{~m}$ away from the compactor & 62.8 & 45.7 & 162.3 \\
\hline No. 9 & At the top of the landfill site (compactor out of operation) $15 \mathrm{~m}$ away from the compactor & 62.6 & 38.7 & 29.0 \\
\hline No. 10 & $\begin{array}{l}\text { The compost site (under the landfill, direct distance } 120 \mathrm{~m} \text { from the compactor (when in } \\
\text { operation) and } 15 \text { metres below the top of the site }\end{array}$ & 68.8 & 35.3 & 67.7 \\
\hline No. 11 & Zolná & 69.9 & 28.7 & 7.8 \\
\hline No. 12 & Očová & 67.4 & 29.7 & 25.0 \\
\hline No. 13 & Lieskovec & 64.5 & 56.2 & 25.9 \\
\hline No. 14 & Zvolenská Slatina & 64.2 & 56.2 & 26.2 \\
\hline
\end{tabular}

al., 2015). This value is to a significant extent the result of the movement of vehicles near the sampling site.

Higher levels of daily and annual mean $\mathrm{PM}_{10}$ concentrations are associated with an increase in mortality and lung function impairment. The recommended maximum value, as stated in the WHO Guideline Values from 2006 for acceptable health risks and short-term effects of $\mathrm{PM}_{10}$ obtained from mean 24-hour interval concentrations, is $\mathbf{5 0}$ $\mu \mathrm{g} \cdot \mathrm{m}^{-3}$. As for long-term effects, the recommended value is much lower and should not surpass $20 \mu \mathrm{g} \cdot \mathrm{m}^{-3}$. Exceeding of these concentrations heightens the risk of mortality, e.g. annual average concentration of $70 \mu \mathrm{g} \cdot \mathrm{m}^{-3}$ can raise such risk by $15 \%$.

The limits for mass concentration $\mathrm{PM}_{10}$ and $\mathrm{PM}_{2.5}$ particles applied in Slovakia are equally strict. According to the Government Decree No. 244/2016 Coll. on air quality as amended, the daily limit for $\mathrm{PM}_{10}$ is $50 \mu \mathrm{g} \cdot \mathrm{m}^{-3}$ and the upper and lower threshold value of $35 \mu \mathrm{g} \cdot \mathrm{m}^{-3}$ and $25 \mu \mathrm{g} \cdot \mathrm{m}^{-3}$ respectively should not be exceeded more than 35 times per year. The daily limit for $\mathrm{PM}_{2.5}$ is not specified. The annual average for $\mathrm{PM}_{10}$ is $40 \mu \mathrm{g} \cdot \mathrm{m}^{-3}$ and for $\mathrm{PM}_{2.5}$ is $20 \mu \mathrm{g} \cdot \mathrm{m}^{-3}$.

The results of the measurement point to "diffusivity" ultrafine particles and microparticles from landfill site to rural area in case of dry and windless weather conditions. Measured UFPs and MP at varying distances and in different wind directions from the landfill (at the boundary line, 2-4 km or more from the boundary line, see Figure 1) are labelled as background concentrations. It is reasonable to expect during long-term stable weather that concentrations of UFPs and MP would decrease with increasing distance from the landfill; in most cases where both were measured, they did. Where this did not happen, an external source is suspected. But no correlation was observed between the measurements at the landfill and the background sites when located $7 \mathrm{~km}$ away from a landfill (Chalvatzaki et al., 2010).

Interesting findings by (Chalvatzaki et al., 2015) reveal that the percentage contributions of road and wind-blown dust to the $\mathrm{PM}_{10}$ concentrations on weekdays were near the unpaved road equal to 76 and $1 \%$, respectively. The influence of the background concentration is estimated at close to $23 \%$. Thus, contribution of wind-blown dust to the $\mathrm{PM}_{10}$ concentrations directly at the landfill is very modest, but the speed and force of wind represent the most significant factors in terms of particle distribution towards the adjacent villages.

Humans perceive the air near a landfill site as rather dusty. It may be caused by irritation of respiratory system by coarse particles $(>10 \mu \mathrm{m})$ in aerosol: The coarse aerosol, however, does not have adverse health effects. Conversely, finer particles $(<10 \mu \mathrm{m})$ penetrate deeper parts of the respiratory tract. It is likely that people do not perceive higher concentrations of ultrafine particles, which can be harmful for human health, as excessive air pollution. This even more stresses the seriousness of ultrafine particulate air pollution. The findings by Ray et al. (2005), demonstrate higher incidence of respiratory symptoms, airway inflammations, lung function impairment and a number of different health problems of people working in the waste disposal field.

\section{CONCLUSIONS}

Measurements of the concentration of ultrafine particles (10-100 $\mathrm{nm})$ and microparticles (0.1-10 $\mu \mathrm{m})$ were 
performed at a municipal solid waste landfill in long-term stable dry, windless weather (only short-term fluctuations in wind speed with $v<1 \mathrm{~m}^{-1}$ ). This way we obtained data on the lowest particulate concentrations at the landfill and its surrounding area.

During windless weather conditions, there are relatively low concentrations of ultrafine particles in the air also at the landfill site and in most of cases they range from 2,500 to 5,000 particles per $\mathrm{cm}^{3}$. The concentrations may rise rapidly up to 14,000 particles per $\mathrm{cm}^{3}$ only in the close proximity of an operating compactor or waste collection vehicles transporting the waste to the landfill.

The measurement results suggest that even in calm weather ultrafine particle number concentrations decreased considerably with increasing distance from the source. In terms of health risks, the compactor operator seems to be the most vulnerable individual working at the landfill site.

The results can be generalised to all landfills with untreated municipal waste. Particulate dispersion is minimal in these conditions and the operation of a compactor at a landfill does not affect the concentration of UFPs and MP in the surrounding areas of the waste site.In the next stages of the study, the measurements will be performed again in dry weather, at different wind speeds and in four directions towards the closest villages situated 2 to $4 \mathrm{~km}$ away from the landfill. This should enable definition of the contribution of the landfill to the overall air pollution by ultrafine particles and microparticles in the adjacent villages.

\section{ACKNOWLEDGMENTS}

This research was supported by the Slovak Grant Agency VEGA under contract No. VEGA 1/0547/15 "Experimental measurement and modelling of fugitive emissions" and KEGA under contract No. 030UMB-4/2017 "Educational Centre for Integrated Safety".

\section{REFERENCES}

Carducci A., Tozzi E., Rubulotta E., Casini B., Cantiani L., Rovini E., Muscillo M., Pacini R. (2000). Assessing airborne biological hazard from urban wastewater treatment. Water Research 34, 11731178. doi:10.1016/S0043-1354(99)00264-X

COM (2008). Green Paper on the management of bio-waste in the European Union. Brussels.
Country profiles of Environmental Burden of Disease - Czech Republic (2009). Public Health and the Environment Geneva. Geneva. https://www.who.int/quantifying_ehimpacts/national/countryprofile/czechrepublic.pdf

Country profiles of Environmental Burden of Disease - Slovakia (2009). Public Health and the Environment, Geneva. Geneva. http://www. who.int/quantifying_ehimpacts/national/ countryprofile/ slovakia. pdf?ua=1

Chalvatzaki E., Glytsos T., Lazaridis M. (2015). A methodology for the determination of fugitive dust emissions from landfill sites. International Journal of Environmental Health Research 3123, 1-19. do i:10.1080/09603123.2014.989491.

Chalvatzaki E., Lazaridis M. (2010): Estimation of greenhouse gas emissions from landfills: Application to the akrotiri landfill site (CHANIA, GREECE). Global NEST Journal 12(1), 108-116.

Chalvatzaki E., Kopanakis I., Kontaksakis M., Glytsos T., Kalogerakis, N. Lazaridis M. (2010). Measurements of particulate matter concentrations at a landfill site (Crete, Greece). Waste Management 30, 2058-2064. doi:10.1016/j.wasman.2010.05.025.

Crisp J. (2017). 23 EU countries are breaking European air quality laws. 7.2.2017. Dostupné na: www.EurActiv.com

EPA (2008). Background Information Document for Updating AP42 Section 2.4 for Estimating Emissions from Municipal Solid Waste Landfills. EPA/600/R-08-116 September 2008.

Hama S.M., Monks P.S., Cordell, R.L. Monitoring of Ultrafine Particle Number Concentration and Other Traffic-related Air Pollutants at One Urban Background Site in Leicester, over The Course of a Year. http://www.nanoparticles.ch/archive/2015_Hama_PO.pdf

US EPA (2015). Emission Guidelines, Compliance Times, and Standards of Performance for Municipal Solid Waste Landfills; US EPA. Federal Register 80(166), August 27, 2015, Proposed Rules.

Keith K. McDamel (1987). High concentration boric acid sqlidification process. Patent 4,664,895.

Macklin Y., Kibble A., Pollitt F. (2011). Impact on Health of Emissions from Landfill Sites: Advice from the Health Protection Agency, Health Protection Agency.

Morawska L., Ling X., Jayaratne R. (2009). Nano and ultrafine particle number concentrations in different environments: application towards air quality regulations. In 19th International Clean Air and Environment Conference, 6-9 September 2009, Perth Convention Exhibition Centre, Perth, WA. This file was downloaded from: https://eprints.qut.edu.au/75159/.

Morawska L , Ristovski Z., Jayaratne ER et al. (2008). Ambient nano and ultrafine particles from motor vehicle emissions: characteristics, ambient processing and implications on human exposure. Atmos Environ; 42: 8113-38.

Ray M.R., Roychoudhury, S., Mukherjee, G., Roy, S., Lahiri, T. (2005). Respiratory and general health impairments of workers employed in a municipal solid waste disposal at an open landfill site in Delhi. International Journal of Hygiene and Environmental Health 208, 255-262. doi:10.1016/j.ijheh.2005.02.001

WHO - Europe (2007). Population health and waste management: scientific data and policy options. Report of a WHO workshop, Rome, Italy 29-30 March 2007, World Health Organization. 